\title{
A decrease in reports on road-killed animals based on citizen science during COVID-19 lockdown
}

\author{
Daniel Dörler ${ }^{\text {Corresp., Equal first author, } 1 \text {, Florian Heigl }}{ }^{\text {Equal first author, } 1}$ \\ ${ }^{1}$ Institute of Zoology, University of Natural Resources and Life Sciences, Vienna, Vienna, Austria \\ Corresponding Author: Daniel Dörler \\ Email address: daniel.doerler@boku.ac.at
}

Background. To avoid the uncontrolled spread of Covid-19 in early 2020 many countries have implemented strict lockdown measures for several weeks. In Austria, the lockdown in early spring has led to a significant drop in human outdoor activities, especially in road traffic. In Project Roadkill, a citizen science project which aims to collect data on road-killed animals, we observed a significant decrease in reported roadkills. Methods. By asking the citizen scientists through a survey how their travelling routines were affected, we investigated if the observed decrease in roadkills was grounded in less animals being killed by traffic, or in citizen scientists staying at home and thus reporting less road-killed animals. Results. A majority of the respondents stated that they felt to have reported less roadkills during the lockdown, regardless if they changed their travelling routine or not. This observation in combination with the overall decrease in road traffic indicates that fewer animals were killed during the lockdown. We conclude that when analyzing citizen science data, the effects of lockdown measures on reporting behaviour should be considered, because they can significantly affect data and interpretation of these data. 


\section{A decrease in reports on road-killed animals based on 2 citizen science during Covid-19-lockdown}

3

Daniel Dörler ${ }^{1 *}$, Florian Heig1 ${ }^{1 *}$

${ }^{1}$ Institute of Zoology, University of Natural Resources and Life Sciences, Vienna, Gregor Mendel-Str. 33, 1180 Vienna

Corresponding Author:

Daniel Dörler ${ }^{1}$

Gregor Mendel-Str. 33, Vienna, 1200, Austria

Email address: daniel.doerler@boku.ac.at

*Both authors contributed equally to this work.

\section{Abstract}

Background. To avoid the uncontrolled spread of Covid-19 in early 2020, many countries have implemented strict lockdown measures for several weeks. In Austria, the lockdown in early spring has led to a significant drop in human outdoor activities, especially in road traffic. In Project Roadkill, a citizen science project which aims to collect data on road-killed animals, we observed a significant decrease in reported roadkills.

Methods. By asking the citizen scientists through a survey how their travelling routines were affected, we investigated if the observed decrease in roadkills was grounded in less animals being killed by traffic, or in citizen scientists staying at home and thus reporting less road-killed animals.

Results. A majority of the respondents stated that they felt to have reported less roadkills during the lockdown, regardless if they changed their travelling routine or not. This observation in combination with the overall decrease in road traffic indicates that fewer animals were killed during the lockdown. We conclude that when analyzing citizen science data, the effects of lockdown measures on reporting behaviour should be considered, because they can significantly affect data and interpretation of these data.

\section{Introduction}

The global Covid-19-pandemic is affecting human activities and lives in a way like never before in our lifetime. To avoid unnecessary deaths of thousands of people due to excessive demands on our health systems (Anderson et al., 2020), most governments all over the planet have installed strict measures to slow down infection rates in the population (WHO, 2020). In Europe, many people have experienced curfews or strict limitations to leaving the house or apartment since March 2020 (Hale et al., 2020). Activities have been reduced to necessary services, such as the 
40 transportation and selling of food or drugs (Hale et al., 2020). Austria has been among the first 41 countries in Europe to implement strict limitations to leaving one's home in mid-March 2020, 42 more exactly from March 16 to April 14 (Hale et al., 2020). During this time period people living 43 in Austria only were allowed to go outside for five reasons: (i) going to work if one is working in 44 an essential job (e.g. in supermarkets or pharmacies), (ii) to go shopping for food or drugs, (iii) 45 to help other people who cannot care for themselves, (iv) to take a short walk outside always 46 keeping at least one meter distance to other people and (v) to save your life in case of life47 threatening events (e.g. fire) in your home (Republik Österreich, 2020). This meant that many 48 people were working from home, were working short hours or lost their jobs, reducing activities 49 or travelling in the country to a minimum (IIASA, 2020). This reduction of human activities in 50 quality due to a dramatic decrease in industrial activities and traffic (Zambrano-Monserrate, Ruano \& Sanchez-Alcalde, 2020). Furthermore, many reports on "nature recovering" during lockdowns all over the world where shared on popular media and social media, showing wildlife in settled areas (Rutz et al., 2020; Bar, 2020), suggesting that negative effects of factors usually influencing animal activity or habitat suitability (e.g. habitat reduction, noise-, light-, air-, or water-pollution, hunting, or roads) were decreasing in their extent. Helm (2020) states that at the moment the evidence for immediate impacts of the COVID19 restrictions on wildlife and environmental protection including the impact of reduced road traffic on roadkill numbers is largely anecdotal so far and based on the expected consequences rather than new data. Roads can have positive or negative influence on animals, depending on the species, season or road characteristics (Rytwinski \& Fahrig, 2015). The most direct negative influence of roads on vertebrates is certainly roadkills (Clevenger, Chruszcz \& Gunson, 2003).

Several projects focus on collecting data of road-killed animals and study its impact on animal population (Schwartz, Shilling \& Perkins, 2020). The aims of these projects are to get an overview of where animals are being road-killed in order to investigate the underlying reasons and to be able to mitigate hotspots. Projects in the USA, Taiwan, South Africa, Great Britain or the Czech Republic involve citizen scientists in data collection (see http://globalroadkill.net/). In citizen science, research projects are conducted in collaboration with or completely by laypeople (Vohland et al., 2021). In some projects (e.g. Dieren onder de wielen by Natuurpunt in Belgium; https:/old.waarnemingen.be/vs/start) citizen scientists monitor single roads at regular intervals, but in most projects citizen scientists report opportunistic data on road-killed animals during their daily routine (Bíl et al., 2020; Shilling et al., 2020), which is a common approach in many ecological citizen science projects (Van Strien, Van Swaay \& Termaat, 2013; Horns, Adler \& Şekercioğlu, 2018). In these projects, interested people are reporting data mostly via an app or an online form when they observe a dead animal on the road. Usually, they take a picture, identify the animal species and provide the GPS coordinates of the roadkill (Shilling et al., 2020). Although it is usually more difficult to analyze opportunistic data (Planillo et al., 2021; Van Eupen et al., 2021), most projects have opted for this method, as the involvement of citizen scientists in opportunistic data collection offers many advantages. Through citizen science it is 
80 possible to sample a large geographical area (Theobald et al., 2015), to bring new expertise into

81 the project, and last but not least, provide opportunities for topical education and science

82 communication (e.g. Shilling, Perkins \& Collinson, 2015; Vercayie \& Herremans, 2015; Heigl et

83 al., 2017; Kelemen-Finan, Scheuch \& Winter, 2018; Chyn et al., 2019). In general, citizen

84 science is already massively contributing to international biodiversity monitoring (Chandler et

85 al., 2017).

86 Due to involvement of the public in the data collection process, we expected an influence of the

87 Covid -19-lockdown measures on reported numbers of road-killed animals. In the US, a decline

88 in wildlife vehicle collisions in California, Idaho and Maine following the stay-at home orders

89 from the government was reported (Shilling et al., 2021). In Australia, an investigation reported a

90 decrease of roadkill numbers by 48\% during the lockdown in April 2020 on a road section

91 consisting of $18 \mathrm{~km}$, which was studied on a regular basis for the last 5 years (Driessen, 2021).

92 Łopucki et al. (2021) observed a decrease in road-killed hedgehogs by 50\% in comparison to

93 previous two years of monitoring in the city of Chelm (Poland) during lockdown. Furthermore, a

94 recent study showed a decline in roadkill numbers from eleven, mostly European, countries (Bíl

95 et al., 2021), not including Austria. However, after the lockdown the numbers rose again to the

96 previous level.

97 These investigations all have in common that they are based on data that could also be

98 consistently collected during lockdown periods (e.g. police reports, professional monitoring,

99 carcass removal), but not on citizen science data. One study even excluded data based on citizen

100 science from analyses due to potential confounding effects during lockdown periods (Bíl et al.,

101 2021). It is therefore crucial to understand what kind of effects lockdowns have on citizen

102 science data to address potential biases or confounding effects.

103 In Austria, Project Roadkill is conducted by a team of 4 people since 2013. In the project, we

104 aim to minimize the number of roadkills. For this, we investigate the influencing factors of

105 traffic and of the landscape surrounding roads on vertebrates. The project is in its first stage,

106 which is to get an overview of the numbers and distribution of roadkills using a citizen science

107 approach (Heigl et al., 2017; Bíl et al., 2020). In Project Roadkill citizen scientists report road-

108 killed animals they encounter on roads via apps for Android or iOS, or by the project's website

109 (www.roadkill.at/en).

110 The project allows for every vertebrate species to be reported, including small mammals like

111 hedgehogs or mice, amphibians, reptiles and birds, but also wildlife such as deer, wild boar or

112 hares, that are categorized as huntable wildlife in Austria (Sternath \& Dutter, 2006). Participants

113 mainly report from suburban areas and high level roads (Heigl et al., 2016). The citizen science-

114 approach has been shown to be a feasible one to investigate roadkill (Shilling, Perkins \&

115 Collinson, 2015; Heigl et al., 2017; Chyn et al., 2019; Yue, Bonebrake \& Gibson, 2019; Bíl et

116 al., 2020; Englefield et al., 2020), since citizens cover long stretches of roads every day (e.g.

117 when riding their bikes as a hobby or when commuting to work). Therefore, during the Covid-19

118 lockdown we immediately experienced a decrease in the number of roadkill reports compared to

119 the previous years (Fig. 1). 
120

121

122

123

124

125

126

127

128

129

130

131

132

133

134

135

136

137

138

139

140

141

142

143

144

145

146

147

148

149

150

151

152

153

154

155

156

157

\section{Insert Figure 1}

In previous years, numbers of reported roadkills in many species were rising in spring due to animal migration to breeding sites (e.g. Common toad, Bufo bufo) or for search of food (e.g. hedgehogs, Erinacaeus sp.) after hibernation. The overall rise in numbers of roadkill reports was less pronounced in spring 2020 than in the spring seasons of the previous years. However, at this time we did not know if this drop was a result of fewer animals being killed on roads due to reduced traffic as was the case in previous investigations (Nguyen et al., 2020; Driessen, 2021). Another explanation could be that the participants in the project were traveling less on roads and therefore could not report the same amount of roadkills than before, although the number of roadkills would be unchanged. The difficulty of distinguishing between ecological and sociological factors (observer bias) influencing the data collected in ecological citizen science projects is well known and has been investigated on several occasions. For example, we know that weekend bias occurs in some projects (Courter et al., 2013; Cooper, 2014) or that data is more often reported in the vicinity of settlements or roads (Johnston et al., 2020). However, the behavioral changes brought about by the lockdown measures are unique and need to be studied in detail to see how these changes affect the ecological data collected in citizen science projects. Still, these two influences must be strictly differentiated in the interpretation of the data.

Therefore, the aim of the present study is to investigate how the strict limitations on leaving ones home in Austria during the first Covid-19 lockdown in spring 2020 was affecting the data collection in Project Roadkill. We tested the hypothesis that the drop of roadkill reports was due to changed travel behavior of our participants by conducting a survey among Austrian project participants. The results of this investigation will have implications for further analyses regarding data collected during the lockdown period, not only in Project Roadkill but in all citizen science projects which rely on opportunistic ecological data collection.

\section{Materials \& Methods}

To test the hypothesis, we conducted a survey among participants of Project Roadkill. At the beginning of April 2020, when this survey was sent out, Project Roadkill had 853 citizen scientists coming from 33 countries. The survey was designed for participating citizen scientists in Austria because (I) the focus of the project is on Austria, (II) most data is submitted by Austrian citizen scientists, and (III) the specific lockdown measures differed between countries. The survey was open from April 20 - May 04, 2020 and consisted of seven primary questions and nine sub-questions that asked for more detailed information if specific primary questions were stated positively. The survey language was German. A translation of the survey is available in Appendix 1. Therefore, the participants had to answer 7 questions minimum and 16 questions maximum. 
158 Citizen scientists were informed about the survey via the in-app push message function on April

159

160

161

162

163

164

165

166

167

168

169

170

171

172

173

174

175

176

177

178

179

180

181

182

183

184

185

186

187

188

189

190

191

192

193

194

195

196

197

20,2020. Citizen scientists who opened the app got a notification on the main screen that a new message has arrived. By clicking on this notification, they could read the message including a link to the survey. The push message was sent to all citizen scientists regardless of the area they are reporting roadkills from. Therefore, the message specifically asked for citizen scientists in Austria. Citizen scientists who report roadkills using the website did not get the push-message. Additionally, we sent the survey link via the newsletter mailing list of Project Roadkill on April 20,2020 . This information was also given in German and was again specifically asking citizen scientists in Austria to participate in the survey. Only people actively signing up for the newsletter receive these newsletters. Consequently, the newsletter recipients do not cover all citizen scientists of Project Roadkill and might also include people who are not reporting roadkills at all but are just interested in the topic. Reminders for the survey were sent after 3 days and 10 days, respectively, via push messages and the newsletter.

The survey was conducted with the software Lime Survey (version 3.21.1). In the following table (Table 1) we list all questions types we used for the individual questions.

\section{Insert Table 1}

Since the exceptions of the curfew rules during the lockdown were unclear to many in this first phase of the pandemic, we ensured that participation in the survey was completely anonymous to avoid any potential concerns by citizen scientists to face legal consequences if they still had to travel during that time period.

So-called primary questions are questions that ask for a general trend (e.g. Did the number of roadkills you reported change in the period from 16.3.2020 to 13.4.2020?), could be stated with yes or no in most cases (exception was question F2, where participants could decide between three different answers, see Table 02 and appendix), and have only one digit in the question code (e.g. F1, F2, F3). Secondary questions asked for more details and usually had a "list (option field)" or a "dual matrix"-structure. Some questions were skipped if answers to primary questions indicated that no more details are necessary (e.g. F3: Question 3: Has the length of your routes from which you potentially report roadkills changed in the period from 16.3.2020 to 13.4.2020? If the answer was "No", secondary questions F31 to F312 were skipped).

The descriptive data analyses were conducted in Microsoft Excel (version 2002, build 12527.21104) using Pivot Charts. Additionally, we conducted Chi-square tests to analyze potential influences of changes (i) in daily route length, (ii) frequency of moving on roads, (iii) overall routing (i.e. if the respondents changed areas through which they move regularly), (iv) road types and (v) modes of transportation using R Studio (V 1.4.1103 (R Core Team, 2018)) with the package gmodels V 2.18.1 (Warnes et al., 2018).

\section{Results}


198

199

200

201

202

203

204

205

206

207

208

209

210

211

212

213

214

215

216

217

218

219

220

221

222

223

224

225

226

227

228

229

230

231

232

233

234

235

236

237

In total, 77 persons completed the survey. In comparison, 179 persons actively reported roadkills in Austria 12 months before the start of the survey. Almost two thirds (64\%) have indicated that they estimated to have reported less roadkills than before the lockdown, $32 \%$ said to have reported the same amount of roadkills, and only $4 \%$ felt to have reported more roadkills than before. A detailed list of the answers can be seen in Table 2.

\section{Insert Table 2}

When asked if anything has changed in the way respondents were moving on roads, more than two thirds $(69 \%)$ stated that the frequency with which they were moving on roads has changed, opposed to $31 \%$ who stated they were moving with the same frequency as before. In addition, more than half of the respondents (55\%) stated that the length of their ways has changed, whereas $45 \%$ stated that the length of their ways did not change at all. The routes, however, did not change for most respondents (75\%), as did the type of roads used (77\%); $23 \%$ said they used other roads than before. The type of transportation used for travelling on roads also did not change for most respondents (68\%); $32 \%$ said they changed the type of transportation used in the time during the lockdown.

To test our hypothesis that the drop of roadkill reports was due to a changed travel behavior of our participants, we compared the answers from the respondents which stated that they did not change the frequency of travel, length of route, the type of road or the type of transportation used to those who reported changes in their travel behavior due to the lockdown. Here we found no significant differences between the two groups $(p=0.454)$. When analyzing all answers from respondents who stated that they did not change the length of their ways, the frequency with which they travelled their route, the type of the road and the type of transportation used, we found a majority of $60 \%$ of respondents who felt to have reported less roadkills compared to $40 \%$ who felt to have reported the same amount of roadkills.

In Table 2, we see that most respondents stated that they reduced the length of their ways and the frequency with which they travel. $55 \%$ of the respondents who reduced the length of their ways and who felt to have reported less roadkills reported a reduction in route length by $75-100 \%$, compared to $50 \%$ of respondents who felt to have reported the same amount of roadkills. Furthermore, $57 \%$ of those respondents who stated that they reduced the frequency with which they travel on roads and who felt to have reported less roadkills also said that they reduced the frequency between 75 and $100 \%$, compared to $25 \%$ of respondents who felt to have reported the same amount of roadkills. Chi-square tests also revealed that the factors reduction of length and reduction in frequency were also the only two that significantly influenced the number of roadkills participants felt to have reported $(p=0.02$ for reduction of length and $p=2.92 \mathrm{e}-08$ for reduction in frequency; change in routes: $p=0.43$; change in roadtype: $p=0.15$; change in transportation: $\mathrm{p}=0.19)$. People who said that the length of their routes has been reduced estimated to report predominantly less roadkills (81\%) or the same amount of roadkills (19\%). Respondents who estimated to have reported more roadkills than before predominantly indicated 
238 that they travelled either longer routes or the length of their routes did not change at all (Fig. 2).

239 However, the interpretation of the answers must be made carefully since only 3 respondents

240 stated that they reported more roadkills.

241

242

243

244

\section{Insert Figure 2}

245

246

247

248

249

250

251

252

253

254

255

256

257

258

259

260

261

262

263

264

265

266

267

268

269

270

271

272

273

274

275

276

277

When we asked for change in frequencies with which people travel on their routes, we saw similar results. Respondents who reported that their frequency of moving on roads increased estimated to have reported more roadkills compared to people who stated that they reported less or the same amount of roadkills, which were moving predominantly less frequently on roads than before.

\section{Insert Figure 3}

The answers indicate that the routes, types of roads used and types of transportation used did not change for a majority of the respondents. All three questions concerning these potential lockdown effects were answered negatively with at least a two-third majority. Consequently, we also could not detect a significant influence of these aspects on the estimated number of reported roadkills. Furthermore, people who felt to have reported more roadkills than before the lockdown did not experience any change in routes, types of roads used or change in transportation mode.

\section{Discussion}

The Covid-19-measures have clearly influenced participants reporting behaviour in Project Roadkill as the feedback from our survey indicates. Almost two thirds of the respondents stated that they estimated to have reported fewer roadkills during the lockdown than before, which is in line with the overall reduced number of reported roadkills during the lockdown period (Fig. $1 \mathrm{~A}$ ). However, in some species (groups) fluctuations are usually very high this time of year as can be seen in Fig. 1. Particularly amphibian roadkill numbers vary significantly this time of year, depending on spring temperatures (e.g. Timm, McGarigal \& Compton, 2007; Scott, Pithart \& Adamson, 2008; Ficetola \& Maiorano, 2016). Therefore, the observed number of amphibian or Common toad roadkills is within the expected fluctuations (Fig. 1, C and E), although on a very low level. Roadkill numbers of other species that also hibernate but are not as temperature sensitive as amphibians, such as mammals (e.g. Wang, 1989), show smaller fluctuations. Numbers for these species in 2020 (e.g. hedgehogs) are outside the range of expected fluctuations (Fig. 1, B and D).

Moreover, we could not detect any significant differences regarding the estimated observed roadkills between people who changed their travelling behavior in any way and those respondents who changed nothing at all. We can see that most respondents experienced profound effects of the lockdown on their travelling routine. The most influential changes according to our results are the reduced 
278 frequency with which people travel on roads and the reduction in route length. This change in 279 travelling routine seems to be the dominant reason for reporting less roadkill, which is in line 280 with previous studies which found that monitored road sections had to be inspected several times 281 a week to cover all potential roadkills (Bager \& Da Rosa, 2011; Ratton, Secco \& da Rosa, 2014). 282 Reasons for this are low persistence rates especially for smaller vertebrates such as amphibians 283 or small mammals (Santos, Carvalho \& Mira, 2011; Santos \& Ascensão, 2019), as they dissolve 284 after a very short period of time, and scavengers that remove carcasses of road-killed animals of 285 roads (Ratton, Secco \& da Rosa, 2014). People who travel longer routes also have a higher 286 chance to encounter road-killed animals. The importance for route length and travel frequency is 287 also confirmed when we look at the group of respondents which felt to have reported more 288 roadkills. Although only a very small number of people (4\% of all respondents), they 289 consistently only reported changes in route length and/or travel frequency, but no overall route 290 changes or changes in types of roads or modes of transportation.

291 Interestingly, however, there was no significant difference in the perceived number of roadkill 292 between the two groups who changed their travel behaviour and those who did not. This result 293 could indicate that possibly fewer animals were road-killed on Austria's roads during the 294 lockdown. This indication is also supported by the fact that fewer vehicles were on the road 295 during the lockdown and thus the probability of a roadkill was reduced. The official traffic 296 statistics show a significant decrease in the number of vehicles on Austrian motorways in March 297 (45\% decrease) and April (54\% decrease) compared to the mean number of vehicles on Austrian 298 motorways for January and February 2020 (ASFINAG, 2020).

299 Several respondents reported a change in the mode of transportation from car to bicycle or going 300 on foot. Although traveling shorter routes, these respondents would have had the chance to 301 discover roadkills they could not see when driving a car e.g. smaller amphibians or mammals. 302 These animals are often overlooked when driving a car due to high velocity (Slater, 2002; 303 Erritzoe, Mazgajski \& Rejt, 2003; Guinard, Prodon \& Barbraud, 2015). Nonetheless, a majority 304 of the respondents who changed from car to going on foot felt to report less roadkills than before. 305 One explanation for this could be that these respondents previously moved in agricultural or 306 silvicultural areas and were moving in settled areas only during the lockdown, where at least 307 some smaller vertebrate species are killed less often (Rodríguez-Castro et al., 2017). However, 308 our survey results for this particular group of respondents do not confirm this explanation. The 309 respondents were moving in settled and agricultural areas in equal shares during the lockdown.

\section{Conclusions}

313 Covid-19 has clearly affected Project Roadkill and its participants. We experienced a significant 314 drop in the number of reported roadkills in 2020 during the lockdown weeks compared to the 315 mean number of reported roadkills in the years 2016-2019. In previous years there have been two 316 peaks in spring during which many road-killed animals have been reported. In 2020, the first 317 peak has been less pronounced and the second peak is missing completely. Two explanations for 
318 this are possible, the second being more likely in our view. Firstly, through the lockdown 319 measures data especially from those animals that get active after hibernation in early spring, such 320 as many amphibians or mammals (e.g. hedgehogs), was not reported due to reduced travel 321 behaviour of our citizen scientists. Secondly, our results indicate that there could be an overall 322 decrease in roadkills due to reduced vehicle numbers on roads during the lockdown.

323 Additionally, travel frequency and travel length seem to be the main factors for a decrease in 324 roadkill reports. We can also see that the majority of the respondents have encountered less 325 roadkills than usual. The investigation shows the duality of Project Roadkill. If fewer participants in our project are on the roads and if this is representative of society, the reports in the project are reduced on the one hand, but also the negative effects of road traffic on vertebrates. Our study indicates that future data analysis based on citizen science projects should take into account the potentially changed reporting behavior of citizen scientists during the Covid pandemic in order to avoid incorrect ecological conclusions.

\section{Acknowledgements}

338

We would like to thank all participants of Project Roadkill, who dedicate their time to the collection of data on road-killed animals all over the world and especially those participants in Austria, that answered the survey and provided invaluable insight on how Covid-19 is affecting their lives. Very special thanks go out to all people who are carrying us all through this pandemic, among them doctors, nurses, employees of supermarkets and many more. 


\section{References}

349 Anderson RM, Heesterbeek H, Klinkenberg D, Hollingsworth TD. 2020. How will country-

350

351

352

353

354

355

356

357

358

359

360

361

362

363

364

365

366

367

368

369

370

371

372

373

374

375

376

377

378

379

380

381

382

383

384

385

386

387

388

389

390

391

392

393 based mitigation measures influence the course of the COVID-19 epidemic? The Lancet 395:931-934. DOI: 10.1016/S0140-6736(20)30567-5.

ASFINAG. 2020. Statistik Dauerzählstellen 2020.

Bager A, Da Rosa CA. 2011. Influence of sampling effort on the estimated richness of roadkilled vertebrate wildlife. Environmental Management 47:851-858. DOI: 10.1007/s00267011-9656-x.

Bar H. 2020. COVID-19 lockdown: animal life, ecosystem and atmospheric environment. Environment, Development and Sustainability. DOI: 10.1007/s10668-020-01002-7.

Bíl M, Andrášik R, Cícha V, Arnon A, Kruuse M, Langbein J, Náhlik A, Niemi M, Pokorny B, Colino-Rabanal VJ, Rolandsen CM, Seiler A. 2021. COVID-19 related travel restrictions prevented numerous wildlife deaths on roads: A comparative analysis of results from 11 countries. Biological Conservation:109076. DOI: 10.1016/j.biocon.2021.109076.

Bíl M, Heigl F, Janoška Z, Vercayie D, Perkins SE. 2020. Benefits and challenges of collaborating with volunteers: Examples from National Wildlife Roadkill Reporting Systems in Europe. Journal for Nature Conservation 54:125798. DOI: 10.1016/j.jnc.2020.125798.

Chandler M, See L, Copas K, Bonde AMZ, López BC, Danielsen F, Legind JK, Masinde S, Miller-Rushing AJ, Newman G, Rosemartin A, Turak E. 2017. Contribution of citizen science towards international biodiversity monitoring. Biological Conservation 213:280 294. DOI: 10.1016/j.biocon.2016.09.004.

Chyn K, Lin TE, Chen YK, Chen CY, Fitzgerald LA. 2019. The magnitude of roadkill in Taiwan: Patterns and consequences revealed by citizen science. Biological Conservation 237:317-326. DOI: 10.1016/j.biocon.2019.07.014.

Clevenger AP, Chruszcz B, Gunson KE. 2003. Spatial patterns and factors influencing small vertebrate fauna road-kill aggregations. Biological Conservation 109:15-26. DOI: 10.1016/S0006-3207(02)00127-1.

Cooper CB. 2014. Is there a weekend bias in clutch-initiation dates from citizen science? Implications for studies of avian breeding phenology. International Journal of Biometeorology 58:1415-1419. DOI: 10.1007/s00484-013-0742-z.

Courter JR, Johnson RJ, Stuyck CM, Lang BA, Kaiser EW. 2013. Weekend bias in Citizen Science data reporting: Implications for phenology studies. International Journal of Biometeorology 57:715-720. DOI: 10.1007/s00484-012-0598-7.

Driessen MM. 2021. COVID-19 restrictions provide a brief respite from the wildlife roadkill toll. Biological Conservation 256:109012. DOI: 10.1016/j.biocon.2021.109012.

Englefield B, Starling M, Wilson B, Roder C, McGreevy P. 2020. The Australian roadkill reporting project - applying integrated professional research and citizen science to monitor and mitigate roadkill in Australia. Animals 10:1-20. DOI: 10.3390/ani10071112.

Erritzoe J, Mazgajski TD, Rejt Ł. 2003. Bird Casualties on European Roads - A Review. Acta Ornithologica 38:77-93. DOI: 10.3161/068.038.0204.

Van Eupen C, Maes D, Herremans M, Swinnen KRR, Somers B, Luca S. 2021. The impact of data quality filtering of opportunistic citizen science data on species distribution model performance. Ecological Modelling 444:109453. DOI: 10.1016/j.ecolmodel.2021.109453.

Ficetola GF, Maiorano L. 2016. Contrasting effects of temperature and precipitation change on amphibian phenology, abundance and performance. Oecologia 181:683-693. DOI: 
394

395

396

397

398

399

400

401

402

403

404

405

406

407

408

409

410

411

412

413

414

415

416

417

418

419

420

421

422

423

424

425

426

427

428

429

430

431

432

433

434

435

436

437

438

439

10.1007/s00442-016-3610-9.

Guinard É, Prodon R, Barbraud C. 2015. Case Study: A Robust Method to Obtain Defendable Data on Wildlife Mortality. Handbook of Road Ecology:96-100. DOI: 10.1002/9781118568170.ch12.

Hale T, Angrist N, Cameron-Blake E, Hallas L, Kira B, Majumdar S, Petherick A, Philips T, Tatlow H, Webster S. 2020. Oxford COVID-19 Government Response Tracker.

Heigl F, Horvath K, Laaha G, Zaller JG. 2017. Amphibian and reptile road-kills on tertiary roads in relation to landscape structure: using a citizen science approach with open-access land cover data. BMC Ecology 17:24. DOI: 10.1186/s12898-017-0134-z.

Heigl F, Stretz CR, Steiner W, Suppan F, Bauer T, Laaha G, Zaller JG. 2016. Comparing roadkill datasets from hunters and citizen scientists in a landscape context. Remote Sensing 8:111. DOI: $10.3390 /$ rs 8100832 .

Helm D. 2020. The Environmental Impacts of the Coronavirus. Environmental and Resource Economics 76:21-38. DOI: 10.1007/s10640-020-00426-Z.

Horns JJ, Adler FR, Şekercioğlu ÇH. 2018. Using opportunistic citizen science data to estimate avian population trends. Biological Conservation 221:151-159. DOI: 10.1016/j.biocon.2018.02.027.

IIASA. 2020. Recovery of the Austrian economy following the COVID-19 crisis can take up to three years. IIASA Policy Brief 26.

Johnston A, Moran N, Musgrove A, Fink D, Baillie SR. 2020. Estimating species distributions from spatially biased citizen science data. Ecological Modelling 422:108927. DOI: 10.1016/j.ecolmodel.2019.108927.

Kelemen-Finan J, Scheuch M, Winter S. 2018. Contributions from citizen science to science education: an examination of a biodiversity citizen science project with schools in Central Europe. International Journal of Science Education 40:2078-2098. DOI: 10.1080/09500693.2018.1520405.

Łopucki R, Kitowski I, Perlińska-Teresiak M, Klich D. 2021. How is wildlife affected by the covid-19 pandemic? Lockdown effect on the road mortality of hedgehogs. Animals 11:1-8. DOI: 10.3390/ani11030868.

Nguyen T, Saleh M, Kyaw M-K, Trujillo G, Bejarano M, Tapia K, Waetjen D, Shilling F. 2020. Special Report 4: Impact of COVID-19 Mitigation on Wildlife-Vehicle Conflict.

Planillo A, Fiechter L, Sturm U, Voigt-Heucke S, Kramer-Schadt S. 2021. Citizen science data for urban planning: Comparing different sampling schemes for modelling urban bird distribution. Landscape and Urban Planning 211:104098. DOI: 10.1016/j.landurbplan.2021.104098.

R Core Team. 2018. R: A Language and Environment for Statistical Computing.

Ratton P, Secco H, da Rosa CA. 2014. Carcass permanency time and its implications to the roadkill data. European Journal of Wildlife Research 60:543-546. DOI: 10.1007/s10344014-0798-z.

Republik Österreich. 2020. 98. Verordnung des Bundesministers für Soziales, Gesundheit, Pflege und Konsumentenschutz gemäß §2 Z1 des COVID-19-Maßnahmengesetzes.

Rodríguez-Castro KG, Ciocheti G, Ribeiro JW, Ribeiro MC, Galetti PM. 2017. Using DNA barcode to relate landscape attributes to small vertebrate roadkill. Biodiversity and Conservation 26:1161-1178. DOI: 10.1007/s10531-017-1291-2.

Rutz C, Loretto MC, Bates AE, Davidson SC, Duarte CM, Jetz W, Johnson M, Kato A, Kays R, Mueller T, Primack RB, Ropert-Coudert Y, Tucker MA, Wikelski M, Cagnacci F. 2020.

PeerJ reviewing PDF | (2021:04:60663:2:0:NEW 5 Oct 2021) 
440

441

442

443

444

445

446

447

448

449

450

451

452

453

454

455

456

457

458

459

460

461

462

463

464

465

466

467

468

469

470

471

472

473

474

475

476

477

478

479

480

481

482

483

484

485
COVID-19 lockdown allows researchers to quantify the effects of human activity on wildlife. Nature Ecology and Evolution 4:1156-1159. DOI: 10.1038/s41559-020-1237-z.

Rytwinski T, Fahrig L. 2015. The Impacts of Roads and Traffic on Terrestrial Animal Populations. Handbook of Road Ecology:237-246. DOI: doi:10.1002/9781118568170.ch28.

Santos RAL, Ascensão F. 2019. Assessing the effects of road type and position on the road on small mammal carcass persistence time. European Journal of Wildlife Research 65. DOI: 10.1007/s10344-018-1246-2.

Santos SM, Carvalho F, Mira A. 2011. How long do the dead survive on the road? Carcass persistence probability and implications for road-kill monitoring surveys. PLOS ONE 6 . DOI: 10.1371 /journal.pone.0025383.

Schwartz ALW, Shilling FM, Perkins SE. 2020. The value of monitoring wildlife roadkill. European Journal of Wildlife Research 66. DOI: 10.1007/s10344-019-1357-4.

Scott WA, Pithart D, Adamson JK. 2008. Long-Term United Kingdom Trends in The Breeding Phenology of The Common Frog, Rana Temporaria. Journal of Herpetology 42:89-96. DOI: $10.1670 / 07-022.1$.

Shilling F, Collinson W, Bil M, Vercayie D, Heigl F, Perkins SE, MacDougall S. 2020.

Designing wildlife-vehicle conflict observation systems to inform ecology and transportation studies. Biological Conservation 251:108797. DOI: https://doi.org/10.1016/j.biocon.2020.108797.

Shilling F, Nguyen T, Saleh M, Kyaw MK, Tapia K, Trujillo G, Bejarano M, Waetjen D, Peterson J, Kalisz G, Sejour R, Croston S, Ham E. 2021. A Reprieve from US wildlife mortality on roads during the COVID-19 pandemic. Biological Conservation 256:109013. DOI: 10.1016/j.biocon.2021.109013.

Shilling F, Perkins SE, Collinson W. 2015. Wildlife/Roadkill Observation and Reporting Systems. Handbook of Road Ecology:492-501. DOI: 10.1002/9781118568170.ch62.

Slater FM. 2002. An assessment of wildlife road casualties - The potential discrepancy between numbers counted and numbers killed. Web Ecology 3:33-42. DOI: 10.5194/we-3-33-2002.

Sternath M, Dutter R. 2006. Der Jagdprüfungsbehelf für Jungjäger und Jagdaufseher. Vienna, Austria: Österreichischer Jagd- und Fischerei-Verlag.

Van Strien AJ, Van Swaay CAM, Termaat T. 2013. Opportunistic citizen science data of animal species produce reliable estimates of distribution trends if analysed with occupancy models. Journal of Applied Ecology 50. DOI: 10.1111/1365-2664.12158.

Theobald EJ, Ettinger AK, Burgess HK, DeBey LB, Schmidt NR, Froehlich HE, Wagner C, HilleRisLambers J, Tewksbury J, Harsch MA, Parrish JK. 2015. Global change and local solutions: Tapping the unrealized potential of citizen science for biodiversity research. Biological Conservation 181:236-244. DOI: 10.1016/j.biocon.2014.10.021.

Timm BC, McGarigal K, Compton BW. 2007. Timing of large movement events of pondbreeding amphibians in Western Massachusetts, USA. Biological Conservation 136:442454. DOI: 10.1016/j.biocon.2006.12.015.

Vercayie D, Herremans M. 2015. Citizen science and smartphones take roadkill monitoring to the next level. Nature Conservation 11:29-40. DOI: 10.3897/natureconservation.11.4439.

Vohland K, Land-Zandstra A, Ceccaroni L, Lemmens R, Perelló J, Ponti M, Samson R, Wagenknecht K (eds.). 2021. The Science of Citizen Science. Cham: Springer International Publishing. DOI: 10.1007/978-3-030-58278-4.

Wang LCH. 1989. Ecological, Physiological, and Biochemical Aspects of Torpor in Mammals and Birds. In: Wang LCH ed. Animal Adaptation to Cold. Berlin, Heidelberg: Springer

Peer] reviewing PDF | (2021:04:60663:2:0:NEW 5 Oct 2021) 
486 Berlin Heidelberg, 361-401. DOI: 10.1007/978-3-642-74078-7_10.

487 Warnes GR, Bolker B, Lumley T, Contributions from Randall C. Johnson are Copyright SAIC488 Frederick RCJ, by the Intramural Research Program IF, of the NIH, Institute NC, for Cancer 489 Research under NCI Contract NO1-CO-12400. C. 2018. gmodels: Various R Programming 490 Tools for Model Fitting.

491 WHO. 2020. Overview of public health and social measures in the context of COVID-19. World 492 Health Organization 2020:1-8.

493 Yue S, Bonebrake TC, Gibson L. 2019. Informing snake roadkill mitigation strategies in Taiwan 494 using citizen science. Journal of Wildlife Management 83:80-88. DOI: 10.1002/jwmg.21580.

Zambrano-Monserrate MA, Ruano MA, Sanchez-Alcalde L. 2020. Indirect effects of COVID-19 on the environment. Science of the Total Environment 728:138813. DOI: 10.1016/j.scitotenv.2020.138813. 


\section{Figure 1}

Comparison of the mean number of roadkills from 2016 to 2019 (black dashed line) with the number of reported roadkills from 2020 (red line).

Strict lockdown measures were effective in calendar weeks 12 to 15 (indicated by the red highlighted area), with gradual relief in the following weeks. Error bars are given for the years 2016-2019. (A) Overall number of reported roadkills. (B) Number of reported mammal roadkills. (C) Number of reported amphibian roadkills. (D) Number of reported hedgehog (Erinacaeus sp.) roadkills. (E) Number of reported Common toad (Bufo bufo) roadkills.
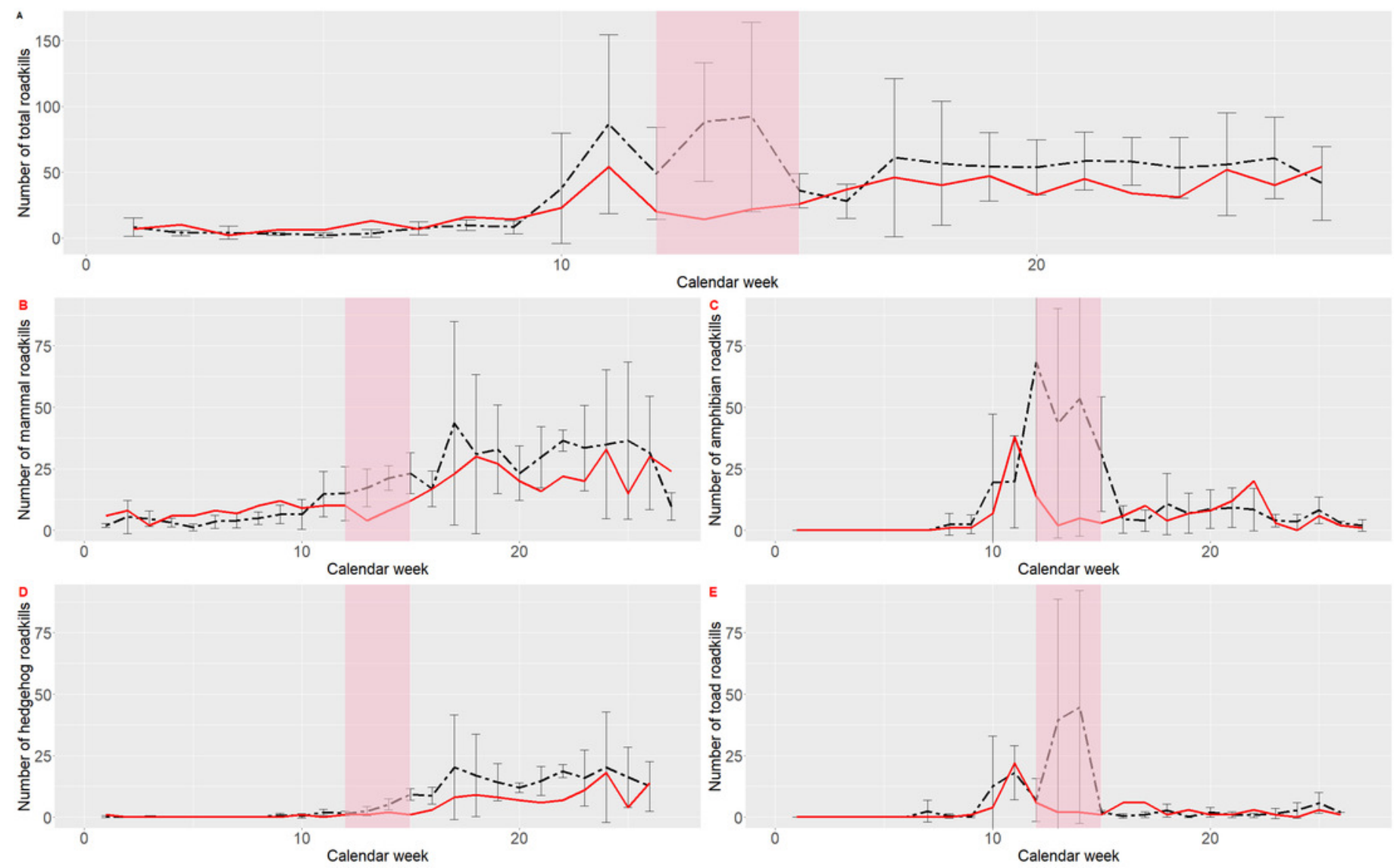


\section{Figure 2}

Mosaic plot of the estimated change in the reported number of roadkills by respondents compared to the length of their routes.

Colours indicate changes in estimated number of reported roadkills (red $=$ increase, green $=$ no change, blue $=$ reduction) .

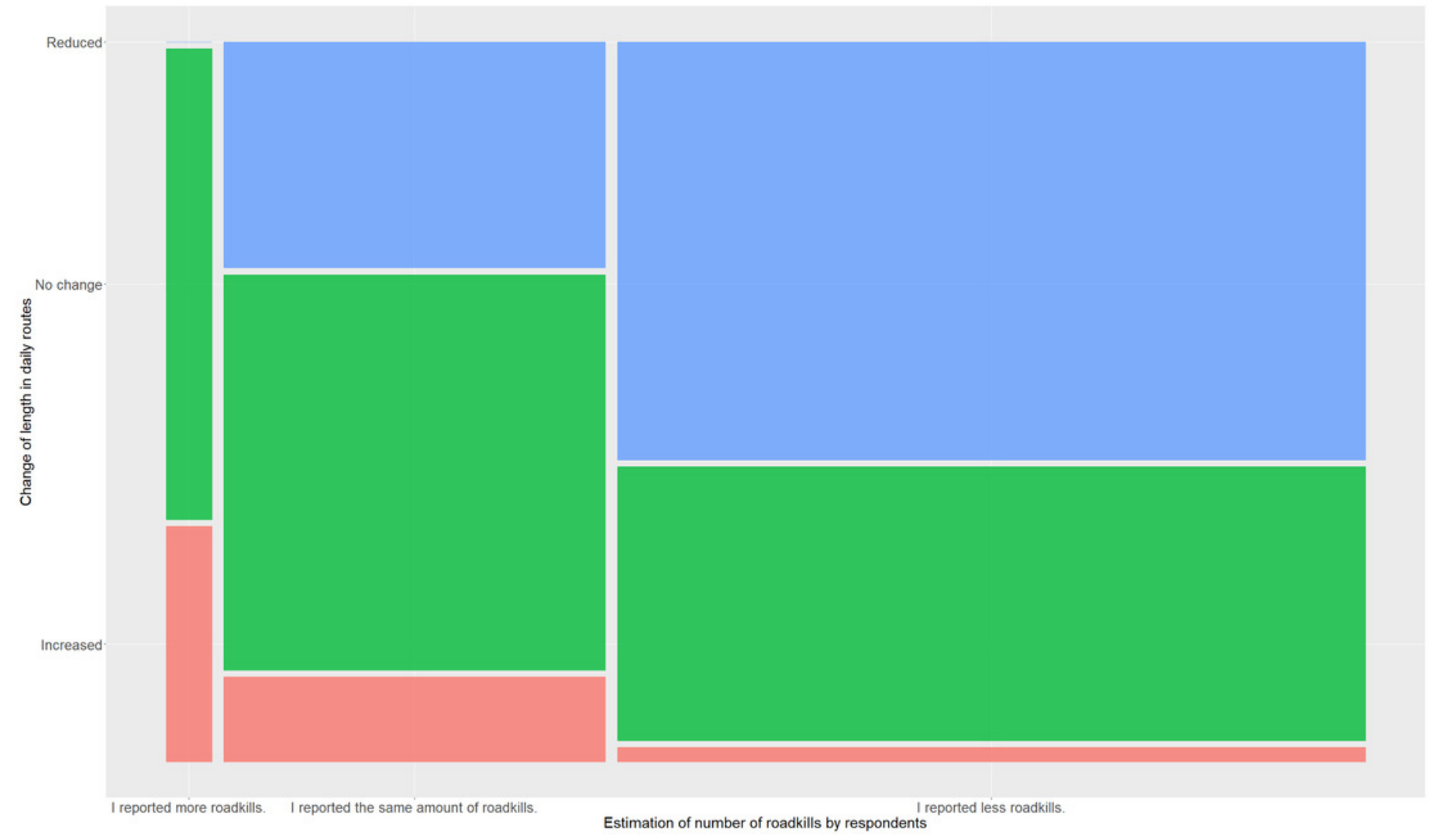




\section{Figure 3}

Mosaic plot of the estimated change in the reported number of roadkills by respondents compared to the frequency with which they were moving on roads.

Colours indicate changes in estimated number of reported roadkills (red $=$ increase, green $=$ no change, blue $=$ reduction) .

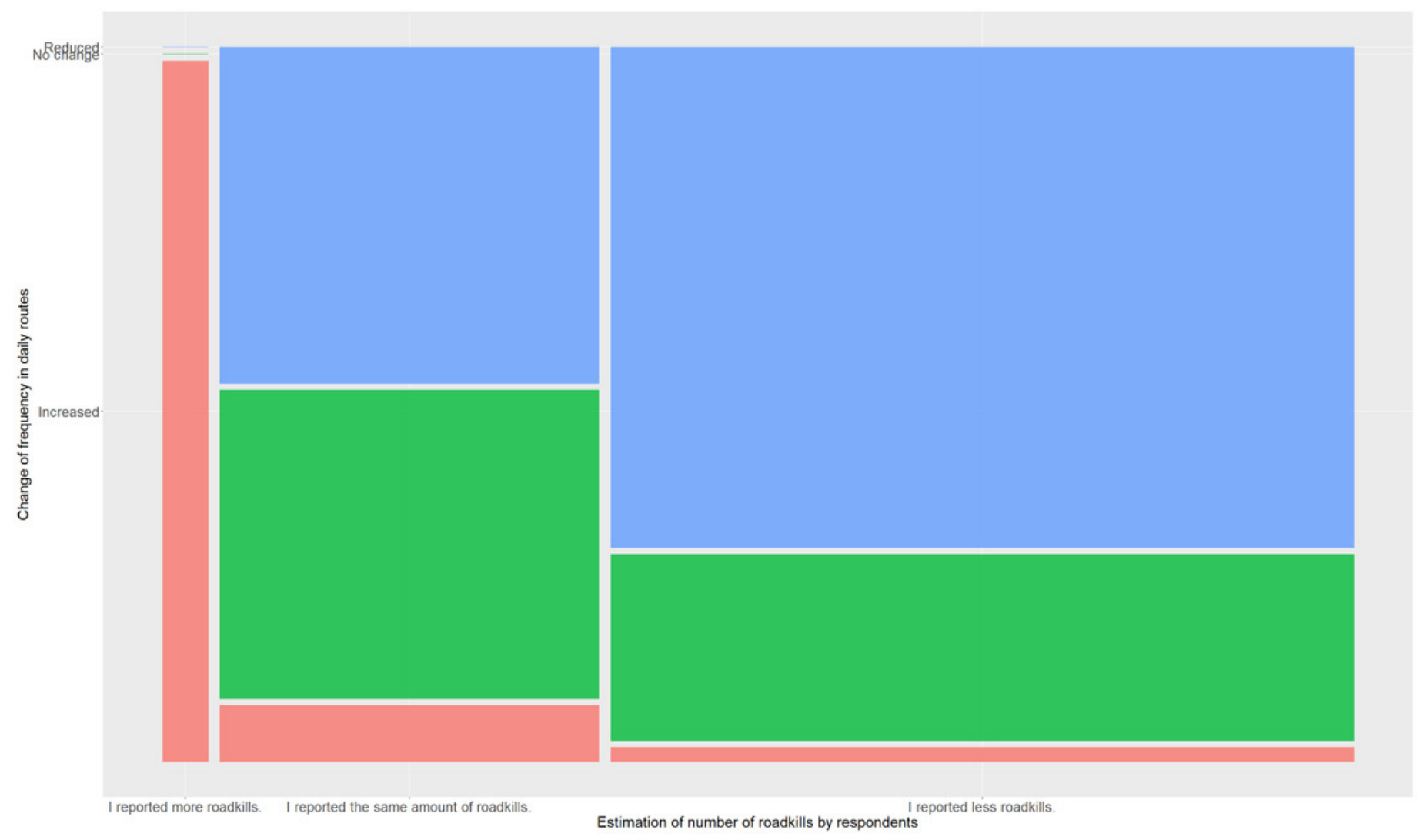




\section{Table $\mathbf{1}$ (on next page)}

Detailed list of all answers to the primary questions of the survey.

Absolute numbers of answers to each question are given. In addition, the percentage in relation to the total number of all submitted answers $(n=77)$ is given in brackets. 
1 Table 1: Detailed list of all answers to the primary questions of the survey. Absolute numbers of

2 answers to each question are given. In addition, the percentage in relation to the total number of

3 all submitted answers $(n=77)$ is given in brackets.

\begin{tabular}{|c|c|c|c|c|c|}
\hline Question & $\begin{array}{l}\text { Response } \\
\text { options }\end{array}$ & $\begin{array}{l}\text { I felt I } \\
\text { reported the } \\
\text { same amount } \\
\text { of roadkills. }\end{array}$ & $\begin{array}{l}\text { I felt I } \\
\text { reported } \\
\text { more } \\
\text { roadkills. }\end{array}$ & $\begin{array}{l}\text { I felt I } \\
\text { reported less } \\
\text { roadkills. }\end{array}$ & $\begin{array}{l}\text { Responses in } \\
\text { total per } \\
\text { response } \\
\text { option }\end{array}$ \\
\hline \multirow{3}{*}{$\begin{array}{l}\text { Has the } \\
\text { length of } \\
\text { your ways } \\
\text { changed? }\end{array}$} & Increased & $3(4 \%)$ & $1(1 \%)$ & $1(1 \%)$ & $5(6 \%)$ \\
\hline & Reduced & $8(10 \%)$ & $0(0 \%)$ & $29(38 \%)$ & $37(48 \%)$ \\
\hline & No change & $14(18 \%)$ & $2(3 \%)$ & $19(25 \%)$ & $35(45 \%)$ \\
\hline \multirow{2}{*}{$\begin{array}{l}\text { Has the } \\
\text { frequency } \\
\text { with which } \\
\text { you travel on }\end{array}$} & Increased & $2(3 \%)$ & $3(4 \%)$ & $1(1 \%)$ & $6(8 \%)$ \\
\hline & Reduced & $12(16 \%)$ & $0(0 \%)$ & $35(45 \%)$ & $47(61 \%)$ \\
\hline $\begin{array}{l}\text { you travel on } \\
\text { roads } \\
\text { changed? }\end{array}$ & No change & $11(14 \%)$ & $0(0 \%)$ & $13(17 \%)$ & $24(31 \%)$ \\
\hline \multirow{2}{*}{$\begin{array}{l}\text { Has the route } \\
\text { of your ways } \\
\text { changed? }\end{array}$} & Yes & $5(6 \%)$ & $0(0 \%)$ & $14(18 \%)$ & $19(25 \%)$ \\
\hline & No & $20(26 \%)$ & $3(4 \%)$ & $35(45 \%)$ & $58(75 \%)$ \\
\hline Has the type & Yes & $9(12 \%)$ & $0(0 \%)$ & $9(12 \%)$ & $18(23 \%)$ \\
\hline
\end{tabular}




\begin{tabular}{|l|l|l|l|l|l|}
\hline $\begin{array}{l}\text { of roads you } \\
\text { use changed? }\end{array}$ & No & $16(21 \%)$ & $3(4 \%)$ & $40(52 \%)$ & $59(77 \%)$ \\
\hline $\begin{array}{l}\text { Has the type } \\
\text { of }\end{array}$ & Yes & $11(14 \%)$ & $0(0 \%)$ & $14(18 \%)$ & $25(32 \%)$ \\
\cline { 2 - 6 } \\
$\begin{array}{l}\text { transportation } \\
\text { you use } \\
\text { changed? }\end{array}$
\end{tabular}

4 


\section{Table 2 (on next page)}

List of question types used for the survey.

The question code corresponds to the individual questions in the survey. The different question types were extracted from Lime Survey. 
1 Table 2: List of question types used for the survey. The question code corresponds to the

2 individual questions in the survey. The different question types were extracted from Lime

3 Survey.

\begin{tabular}{|l|l|}
\hline Question Code & Type \\
\hline F1 & Yes/No \\
\hline F2 & List (option fields) \\
\hline F3 & Yes/No \\
\hline F31 & List (option fields) \\
\hline F311 & List (option fields) \\
\hline F312 & List (option fields) \\
\hline F4 & Yes/No \\
\hline F41 & List (option fields) \\
\hline F411 & List (option fields) \\
\hline F412 & List (option fields) \\
\hline F5 & Yes/No \\
\hline F51n & Dual matrix \\
\hline F6 & \\
\hline
\end{tabular}




\begin{tabular}{|l|l|}
\hline F61n & Dual matrix \\
\hline F7 & Yes/No \\
\hline F71 & Dual matrix \\
\hline
\end{tabular}

4 
